\title{
Má význam zabývat se nízkosacharidovou a ketogenni dietou u osob s diabetem? Editorial
}

\author{
Zdeněk Rušavý \\ Diabetologické centrum I. interní kliniky LF UK a FN Plzeň
}

Komentář k | Editorial on

Krejčí H et al. Nízkosacharidová strava v léčbě diabetes mellitus. Vnitř Lék 2018; 64(7-8): $742-752$.

Jaký je náš dietologický cíl při léčbě diabetu? Domnívám se, že náš cíl je primárně zlepšit a ideálně normalizovat glykemii, snížit variabilitu glykemie v průběhu 24 hod a maximálně omezit riziko hypoglykemie. Rádi bychom dietou snížili rychlost progrese aterosklerózy, ale to se u osob s již rozvinutou aterosklerózou nedaří ani dietou, ani těsnou kontrolou glykemie [1,2]. Podstatně účinnější a rychleji působící je v oblasti prevence kardiovaskulární morbidity a mortality pravidelná fyzická aktivita [3].

Diabetes byl odedávna léčen dietou. Angličan John Rollo doporučoval v roce 1797 diabetikům nízkokalorickou dietu s vysokým obsahem tuků, proteinů a minimálním obsahem sacharidů. Tato ketogenní dieta byla po objevu inzulinu opuštěna, ale ještě v 50 . letech minulého století byl podíl sacharidů v dietě poměrně nízký. Od 80. let minulého století se objevily v USA diety s vysokým obsahem sacharidů a nízkým obsahem tuku. Dieta byla zaměřena na maximální restrikci saturovaných tuků. V posledních 10 letech byla tato dieta kritizována, protože při ní dále stoupal výskyt obezity v populaci a rovněž stoupal výskyt diabetu. Nyní se doporučení vracejí do 50. let minulého století s několika významnými rozdíly. V dietě je doporučován vysoký př́ijem vlákniny a potrava je rozdělena do 2-3 dávek denně. Doporučení České diabetologické společnosti (ČDS) zahrnují i vegetariánskou dietu založenou na ovoci, zelenině a luštěninách.

U osob s diabetem 1. typu je velmi důležitá přesná znalost obsahu sacharidů v každé dávce jídla s přihlédnutím na glykemický index potravy, což je poměrně obtížné. Proto řada osob používá jinou dietu, založenou na nízkém př́vodu sacharidů 80-120 g/den s obvyklým př́jmem proteinů $1-1,5 \mathrm{~g} / \mathrm{kg}$ [4]. Právě o této dietě pojednává přehledný článek MUDr. Krejčí v tomto čísle časopisu. Nízkosacharidové redukční diety vedou ke vzniku ketolátek, které působí anorekticky. Pokud používáme kvalitní zdroje proteinů (maso, ryby, vejce, tvaroh), kvalitní tuky (olivový panenský olej, máslo, sádlo, ořechy) a kvalitní zeleninu, můžeme snáze dosáhnout redukci hmotnosti i zlepšení kontroly diabetu.

Svalové i jaterní buňky u člověka utilizují při lačnění preferenčně volné mastné kyseliny (VMK), po jídle sacharidy - vyplavení inzulinu zvyšuje utilizaci sacharidů. Dieta

\begin{tabular}{|c|c|c|c|c|c|}
\hline & & kcal & bílkoviny & tuky & sacharidy \\
\hline snídaně v 6:00 & $\begin{array}{l}\text { bílá káva (se sójovým mlékem) } \\
3 \text { sušenky (quinoa mouka a vločky, drcené mandle, kousky } \\
\text { sušených švestek, vše smíchané se zralou nastrouhanou hruškou) } \\
3 \text { sušené švestky } \\
5 \text { pražených mandlí }\end{array}$ & 336 & $9 \mathrm{~g}$ & $16 \mathrm{~g}$ & $37 \mathrm{~g}$ \\
\hline oběd ve 13:00 & $\begin{array}{l}200 \text { g jehněčího masa } \\
\text { podušená ćínská kapusta (Pak Choi) } \\
1 \text { „snídaňová“ sušenka (dezert) } \\
2 \text { skleničky prosecca Valdobbiadene } 11,5 \%\end{array}$ & 935 & $37 \mathrm{~g}$ & $59 \mathrm{~g}$ & $27 \mathrm{~g}$ \\
\hline večeře v 19:30 & $\begin{array}{l}\text { pstruh } \\
\text { míchaný salát: čekanka hlávková červená typ Treviso a Chioggia, } \\
\text { řapíkatý celer, čínská kapusta, zelené olivy, nat' petrželky } \\
\text { 1,snídaňová“ sušenka (dezert) } \\
2 \text { skleničky Nero d'Avola }\end{array}$ & 882 & $45 \mathrm{~g}$ & $37 \mathrm{~g}$ & $10 \mathrm{~g}$ \\
\hline celkem & & 2153 & $91 \mathrm{~g}$ & $112 \mathrm{~g}$ & $74 \mathrm{~g}$ \\
\hline
\end{tabular}


s vyšším obsahem sacharidů a nadměrným přívodem energie u diabetiků léčených vysokou dávkou inzulinu může vést $k$ substrátovému pretížení buněk a vyvolat jejich poškození, které se může projevit kardiomyopatií, myopatií a jaterní steatózou. Jediná obrana organizmu v této situaci je zvýšení rezistence k inzulinu [5].

$\checkmark$ roce 2015 se sešla skupina 27 nutričních expertů (USA, Dánsko, Švédsko, Velká Británie, Finsko, Kuvajt, Kanada, Německo) v čele s Robertem Feinmanem a diskutovala výhodnost nízkosacharidové diety u diabetiků 2. typu. Vzniklá publikace $v$ časopise Nutrition vede k vážnému zamyšlení (tab.).

\section{Některé závěry}

Restrikce sacharidů snižuje glykemii i bez snížení hmotnosti. Adherence k nízkosacharidové dietě je stejná nebo lepší proti ostatním dietám. Náhrada sacharidů proteiny je obecně doporučována. Vede ke snížení hmotnosti a zvyšuje objem svaloviny (proteiny > 1,5 g/kg). Celkový a saturovaný tuk $v$ dietě nekoreluje s rizikem kardiovaskulárních (KV) chorob. Náhrada saturovaných tuků sacharidy nemá efekt. „Diet-heart hypothesis" se nepotvrdila. Není korelace mezi tuky v dietě a KV-komplikacemi. Hladiny plazmatických volných mastných kyselin závisejí na per os sacharidech více než na tucích. Přívod saturovaných mastných kyselin $v$ dietě nekoreluje s koncentrací volných mastných kyselin v séru. Restrikce sacharidů $v$ dietě je (mimo hladovění) nejúčinnější při snižování triglyceridů a zvyšování HDL-cholesterolu. Nízkosacharidová dieta vede u diabetes mellitus 2. typu ke snížení nebo vynechání medikace, u diabetes mellitus 1. typu ke snížení dávky inzulinu. Nízkosacharidová dieta nemá vedlejší účinky ve srovnání s medikací.

\section{Závěr}

Nízkosacharidová dieta s vysokým podílem vlákniny je jednou z možností dietní léčby diabetu nebo redukce hmotnosti.

\section{Literatura}

1. Wing RR, Bolin P, Brancati FL et al. [Look AHEAD research group]. Cardiovascular effects of intensive lifestyle intervention in type 2 diabetes. N Engl J Med 2013; 369(2): 145-154. Dostupné z DOI: <http:// dx.doi.org/10.1056/NEJMoa1212914>. Erratum in N Engl J Med 2014; 370(19): 1866.

2. Patel A, MacMahon S, Chalmers J et al. [ADVANCE Collaborative Group]. Intensive blood glucose control and vascular outcomes in patients with type 2 diabetes. N Engl J Med 2008; 358(24): 2560-2572. Dostupné z DOI: <http://dx.doi.org/10.1056/NEJMoa0802987>.

3. Naci $\mathrm{H}$, loannidis JP. Comparative effectiveness of exercise and drug interventions on mortality outcomes: metaepidemiological study. BMJ 2003; 347: f5577. Dostupné z DOI: <https://doi.org/10.1136/ bmj.f5577>.

4. Bernstein RJ. Diabetes solution. The complete guide to achieving normal blood sugars. Hachette Book Group, Inc., USA 2011. ISBN 978-0316182690.

5. Nolan CJ, Ruderman NB, Kahn SE et al. Insulin resistence as a Physiological Defense Against Metabolic Stress: Implications for the Management of Subsets of Type 2 Diabetes. Diabetes 2015; 64(3): 673-686. Dostupné z DOI: <http://dx.doi.org/10.2337/db14-0694>.

6. Feinman RD, Pogozelski WK, Astrup A at al. Dietary carbohydrate restriction as the first approach in diabetes management: Critical review and evidence base. Nutrition 2015; 31(1): 1-13. Dostupné z DOI: $<$ http://dx.doi.org/10.1016/j.nut.2014.06.011>.

prof. MUDr. Zdeněk Rušavý, Ph.D. $\triangle$ rusavy@fnplzen.cz

Diabetologické centrum I. interní kliniky LF UK a FN PIzeň www.fnplzen.cz

Doručeno do redakce 11. 12. 2017 